\title{
PENINGKATAN KOMPETENSI PEDAGOGIK GURU MELALUI SUPERVISI INFORMAL DI SDN MARGOREJO 1 SURABAYA
}

\author{
Umintrah \\ SDN Margorejo 1 Surabaya \\ email: umintrahanwar62@gmail.com
}

\begin{abstract}
Improving Pedagogy Competency of Teacher through Informal Supervision in Margorejo 1 of Surabaya Elementary School. Pedagogic competence is the ability of teachers to manage to learn. The purpose of this study is to improve the pedagogic competence of teachers through informal supervision. The research method used in this study is school action research. This study consists of two cycles, each cycle consists of four activities, namely planning, implementation, observation, reflection. Data collection techniques in this study are observation and checklist. Data analysis techniques in this study were using descriptive quantitative. The results of the school action research showed that the pedagogic competence of teachers increased from cycle to cycle, in the pre-cycle the average value of teacher's pedagogic competence in SDN Margorejo one was 59.79 with $21 \%$ of teachers who had fewer criteria, and $79 \%$ of teachers had sufficient criteria. In the first cycle, there was an increase of $20.83 \%$ in the good criteria. In the second cycle, there was also an increase of $70.82 \%$ in good criteria, from $20.83 \%$ in the first cycle increased to $91.67 \%$ in the second cycle. In this second cycle indicators of achievement of teachers' pedagogic competencies have reached more than $80 \%$ good.
\end{abstract}

Keywords: Pedagogic, Informal Supervision

\begin{abstract}
Abstrak
Peningkatan Kompetensi Pedagogik Guru Melalui Supervisi Informal di SDN Margorejo 1 Surabaya. Kompetensi pedagogik merupakan kemampuan guru dalam mengelola pembelajaran. Tujuan penelitian ini adalah untuk meningkatkan kompetensi pedagogik guru melalui supervisi informal. Metode penelitian yang digunakan dalam penelitian ini adalah penelitian tindakan sekolah. Penelitian ini terdiri dari dua siklus, setiap siklus terdiri dari empat kegiatan, yaitu perencanaan, pelaksanaan, pengamatan, refleksi. Teknik pengumpulan data pada penelitian ini adalah observasi dan ceklis. Teknik analisis data pada penelitian ini adalah menggunakan kuantitatif deskriptif. Hasil penelitian tindakan sekolah menunjukkan kompetensi pedagogik guru meningkat dari siklus ke siklus, pada pra siklus nilai rata-rata kompetensi pedagogik guru di SDN Margorejo I adalah 59,79 dengan 21 $\%$ guru yang memiliki kriteria kurang, dan $79 \%$ guru memiliki kriteria cukup. Pada siklus I terjadi peningkatan 20,83\%. Pada siklus II juga terjadi peningkatan sebesar $70,82 \%$ pada kriteria baik, dari $20,83 \%$ pada siklus I meningkat menjadi $91,67 \%$ pada siklus II. Pada siklus II ini indikator ketercapaian kompetensi pedagogik guru sudah mencapai lebih dri $80 \%$ baik
\end{abstract}

Kata Kunci: Pedagogik, Supervisi Informal 


\section{PENDAHULUAN}

Permendiknas Nomor 13 Tahun 2007 menyatakan bahwa seorang Kepala Sekolah harus menguasai Standar Kompetensi Kepala Sekolah yang terdiri atas: kompetensi kepribadian, kompetensi manajerial, kompetensi supervisi, kompetensi kewirausahaan dan kompetensi sosial. Penjabaran kompetensi supervisi pada intinya adalah supervisi akademis dimana langkahlangkah yang dilakukan adalah merencanakan program supervisi akademik dalam rangka peningkatan profesionalisme guru, melaksanakan supervisi akademik terhadap guru dengan menggunakan pendekatan dan teknik supervisi yang tepat serta menindaklanjuti hasil supervisi akademik terhadap guru dalam rangka peningkatan profesionalismenya.

Guru merupakan tenaga pendidik yang memiliki empat kompetensi yaitu, kepribadian, profesional, pedagogik, dan kompetensi sosial sehingga guru memiliki tanggung jawab besar terhadap siswa, orangtua, kepala sekolah, dan masyarakat. Maka, guru harus benarbenar melaksanakan empat kompetensi tersebut dengan baik. Saat ini kompetensi pedagogik guru dalam melaksanakan tugas pokok dan fungsinya masih kurang. Pemerintah sudah memberikan beberapa tunjnagan berupa tunjangan profesional pendidik, tunjangan kinerja, dan tunjangan makan minum namun masih belum ada kinerja yang sinergis terhadap tugasnya.

Kompetensi pedagogik guru merupakan kemampuan guru untuk mengatur pembelajaran di kelas. Kompetensi ini bisa dilihat dari kemampuan untuk merencanakan program pembelajaran, kemampuan untuk melaksanakan pembelajaran, atau mengelola proses pembelajaran dan kemampuan untuk menilai pembelajaran. Sedangkan pengertian kompensi pedagogik menurut Madhavaram (Mata, 2014, p. 412) "Kompetensi pedagogik sebagai kemampuan dari individu untuk menggunakan koordinasi, menggabungkan secara sinergi sumber yang tampak dan sumber yang tidak tampak untuk mencapai efesiensi dan efektifitas pendidikan.

Kompetensi pedagogik merupakan penguasaan terhadap teori dan prinsipprinsip pembelajaran, pengembangan kurikulum, penggunaan teknologi informasi dan komunikasi dalam proses pembelajaran, komunikasi yang efektif dan secara sopan kepada siswa, melakukan penilaian dan proses evaluasi dari hasil pembelajaran, menggunakan hasil penilaian dan evaluasi untuk tujuan pembelajaran dan melakukan tindakan reflektif untuk meningkatkan pembelajaran.

Ketrampilan mengajar merupakan bagian dari kompetensi pedagogik guru. Komponen dalam kompetensi pedagogik itu: a. kompetensi merencanakan pengajaran. Usaha yang telah dibuat untuk memberdayakan komptensi guru pada area ini adalah dengan melakukan pengarahan dan memungkinkan guru memilki kemampuan mendiskripsikan sasaran, (2) memilih materi, (3) mengorganisasikan materi, (4) menentukan strategi dan metode pembelajaran, (5) menentukan sumber, media, dan alat belajar, (6) mendisain alat penilaian dan evaluasi pembelajaran, (7) 
meenentukan teknik penilain dan evaluasi pembelajaran, (8) mengalokasikan waktu. b. kompetensi proses belajar dan pengajaran : meningkatkan kompetensi proses belajar dan pengajaran yaitu (1) membuka pelajaran, (2) menyampaikan materi, (3) menggunakan media dan metode, (4) menggunakan media pengajaran, (5) menggunakan bahasa komunikatif, (6) memotivasi siswa, (7) mengorganisasi aktifitas siswa, (8) interaksi dengan siswa secara komunikatif, (9) menyimpulkan pelajaran,(10) memberikan timbal balik, (11) melaksanakan penilaian dan evaluasi, (12) menggunakan waktu dengan efektif. c. kompetensi menilai dan menevaluasi belajar dan pembelajaran, (Akhyak, Idrus, \& Bakar, 2013, p. 4).

Kompetensi pedagogik guru sekolah dasar di Indonesia menurut Permendiknas no 16 tahun 2007 adalah 1) menguasai karakteristik peserta didik dari aspek fisik, moral, sosial, kultural, emosional, dan intelektual, 2) menguasai teori belajar dan prinsip-prinsip pembelajaran yang mendidik, 3) mengembangkan kurikulum yang terkait dengan mata pelajaran/bidang pengembangan yang diampu, 4) menyelenggarakan pembelajaran yang mendidik, 5) memanfaatkan teknologi informasi dan komunikasi untuk kepentingan pembelajaran, 6) memfasilitasi pengembangan potensi peserta didik untuk mengaktualisasikan berbagai potensi yang dimiliki, 7) berkomunikasi secara efektif, empatik, dan santun dengan peserta didik, 8) menyelenggarakan penilaian dan evaluasi proses dan hasil belajar, 9) memanfaatkan hasil penilaian dan evaluasi untuk kepentingan pembelajaran, 10) melakukan tindakan reflektif untuk peningkatan kualitas pembelajaran.

Aspek penting dari kompetensi pedagogik guru adalah sikap, pengetahuan, dan ketramplan guru dalam menyesuaikan dengan situasi. Guru yang menguasai kompetensi pedagogik dengan baik akan menjadikan pembelajaran berhasil sehingga sekolah akan berkualitas. Inti dari keberhasilan sekolah adalah pencapaian dari proses pembelajaran yang dilakukan siswa.

Peningkatan kompetensi pedagogik guru bisa dilakukan melalui supervisi. Salah satu pendekatan supervisi yang bisa dilakukan di sekolah adalah supervisi informal. Pengertian supervisi informal menurut Sergiovanni dan Strarrat (1993:291) "informal supervision is comprised of causal encounters that occur between supervisors and teacher and is characterized by frequent informalvisits to teachers classrooms, converstion with teacherabout their work and other activities ". Supervisi informal terdiri dari pertemuan timbal balik yang terjadi antara supervisor dan guru dan ditandai dengan sering kunjungan informal ke ruang kelas guru, percakapan dengan guru tentang pekerjaan mereka dan kegiatan lain.

Pendekatan informal berasumsi bahwa para supervisor utama tentu saja memimpin atau guru berhak dan bertanggung jawab dari semua pengajaran yang berlangsung di dalam sekolah. Kepala sekolah sebagai supervisor adalah mitra bagi guru di tiaptiap kelas untuk setiap situasi pembelajaran. Manakala supervisi informal dilakukan dengan baik pada 
tempatnya, para supervisor utama dipandang dapat memberikan pembinaan secara umum kepada guru dalam peningkatan kualitas pembelajaran.

Walaupun supervisi informal terjadi secara kebetulan, dialog yang dilakukan merupakan dialog profesional tentang berbagai hal berkaitan dengan perbaikan pengajaran. Selama berlangsungnya supervisi informal supervisor diharapkan dapat berperan sebagai konsultan yang edukatif atau narasumber yang berpikiran terbuka serta menjadi pendengar yang baik.

Ciri-ciri supervisi informal menurut Pidarta (2009 : 163) sebagai berikut: (1). Supervisi diadakan tanpa kesepakatan waktu, materi, dan tempat terlebih dahulu, (2.) Supervisi secara mendadak dalam pertemuan informal tertentu, (3). Pembicaraan dalam supervisi bersifat individual yaitu seorang guru berhadapan dengan supervisor, (4). Proses supervisi mirip dengan proses konsultasi. (5). Pada umumnya tidak ada pertemuan balikan (6). Penguatan jarang sekali dilakukan, (7). Tindak lanjut juga tidak diperlukan.

Berdasarkan pendapat diatas supervisi informal lebih bersifat fleksibel dan tidak pada saat yang direncanakan. Suervisi informal dilakukan dimana saja dan kapan saja. Pelaksanaan supervisi informal supervisor melihat guru secara tiba-tiba.

Mencermati hasil analisis Program Supervisi Tahun 2017 pada SDN Margorejo I/ 403 Surabaya secara umum ditemukan beberapa kelemahan yang perlu diperbaiki bagi peningkatan kualitas pembelajaran sekaligus peningkatan profesionalisme guru, seperti: pengembangan indikator dan materi pembelajaran, penggunaan metode pembelajaran yang belum variatif, lemahnya penguasaan guru dalam modelmodel pembelajaran aktif, dan sebagainya.

Melihat kenyataan seperti ini sebagai kepala sekolah sebagai Supevisor berkewajiban untuk membina, membimbing, dan meningkatkan kompetensi pedagogik guru melalui supervisi informal yang secara menyeluruh dan sistematis yang diharapkan setelah kegiatan dilakukan agar terjadi perbaikan yang signifikan dalam kompetensi pedagogik guru di SDN Margorejo I/ 403 Surabaya.

Berdasarkan permasalahan diatas, maka rumusan masalah pada penelitian tindakan sekolah ini adalah "Bagaimana meningkatkan kompetensi pedagogik guru melalui supervisi informal di SDN Margorejo 1 Surabaya?"

Tujuan penelitian tindakan sekolah ini adalah untuk meningkatkan kompetensi pedagogik guru melalui supervisi informal di SDN Margorejo 1 Surabaya. Hipotesis tindakan pada penelitian tindakan sekolah ini adalah supervisi informal dapat meningkatkan kompetensi pedagogik guru di SDN Margorejo 1 Surabaya.

\section{METODE}

Metode penelitian yang digunakan pada penelitian ini penelitaian tindakan sekolah. Penelitian tindakan sekolah merupakan rangkaian tindakan yang digunakan untuk memecahkan masalah yang ada di sekolah. Pelaksanaan pra tindakan dilaksanakan pada 13- 25 Agustus 2018 pelaksanaan siklus I dilaksanakan pada 03 - 15 September 
2018 dan pelaksanaan siklus II dilaksanakan pada 01 - 16 Oktober 2018 Tempat penelitian ini di SDN Margorejo 1 Surabaya. Pada siklus I dan siklus II dengan tahap sebagai berikut:

a. Perencanaan. Pada tahap siklus I kegiatan yang dilakukan adalah:

1) Merumuskan masalah yang akan dicari solusinya

2) Merumuskan tujuan penelitian

3) Merumuskan indikator keberhasilan penelitian

4) Merumuskan langkah-langkah kegiatan penelitian

5) Menyusun instrumen pengamatan dan evaluasi;

6) Menenentuan waktu dan tempat pelaksanaan penelitian

b. Pelaksanaan

Pada tahap ini peneliti melaksanakan rencana tindakan kegiatan supervisi dilakukan secara tiba-tiba. Kepala sekolah memntau cara guru di kelas mengajar. Kepala sekolah memasuki kelas setiap hari satu persatu dan mencatat kekurangan guru

c. Pengamatan dan evaluasi

Dalam melakukan pengamatan terhadap kompetensi pedagogik guru di kelas, kepala sekolah mengamati seluruh aspek kompetensi pedagogik guru.

d. Refleksi

Untuk mengetahui hasil dariproses pelaksanaan tindakan yang telah dilakukan, maka dilakukan refleksi. Hasil dari refleksi akan dijadikan dasar untuk memperbaiki tindakan pada siklus selanjutnya. Setelah dilakukan refleksi.
Instrumen yag digunakan instrumen observasi dan ceklis dokumen untuk melihat penguasaan kompetensi pedagogik guru.

Teknik pengumpulan data pada penelitian tindakan sekolah adalah menggunakan observasi dan checklist dokumen dilakukan peneliti menilai dalam kompetensi pedagogik guru. Analisis data menggunakan analisis kuantitatif deskriptif yaitu menyajikan data dalam bentuk grafik, mencari ratarata, nilai tertinggi dan nilai terendah. Indikator Ketercapaian penelitian tindakan sekolah dalam ini untuk peningkatan kompetensi pedagogik guru adalah $80 \%$ guru memiliki kompetensi pedagogik pada kriteria baik.

\section{HASIL DAN PEMBAHASAN}

Pada kegiatan pra siklus, dilakukan peneliti pada hari Senin tanggal 13-25 Agustus 2018. Berdasarkan hasil pengamatan pada semua guru tentang kompetensi pedagogik guru diperoleh data pada Diagram 1 di bawah ini:

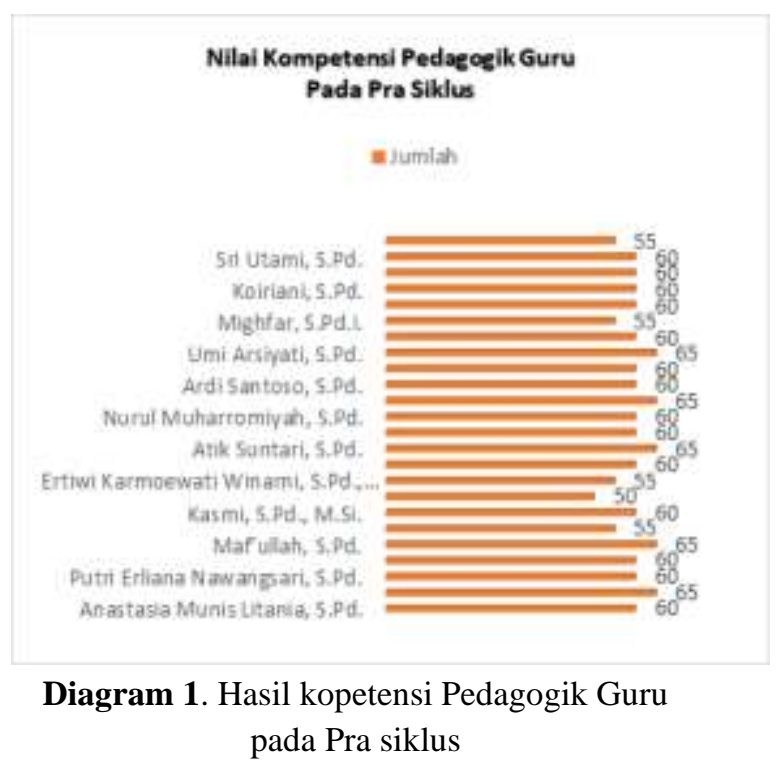


Berdasarkan hasil pra siklus nilai rata-rata kompetensi pedagogik guru di SDN Margorejo satu adalah 59,79. Nilai yang terendah adalah 50 dan nilai yang tertinggi adalah 65 . Berikut ini tabel 1 hasil rekapitulasi hasil pra siklus.

\section{Tabel 1 Rekapitulasi Pra Siklus}

\begin{tabular}{|c|c|c|c|}
\hline Nilai & Jumlah & Prosentase & Kriteria \\
\hline 50 & 1 & $4,167 \%$ & Kurang \\
\hline 55 & 4 & $16,67 \%$ & Kurang \\
\hline 60 & 14 & $58,33 \%$ & Cukup \\
\hline 65 & 5 & $20,83 \%$ & Cukup \\
\hline
\end{tabular}

Berdasarkan hasil rekapitulasi hasil Pra siklus diatas, dapat disimpulkan $21 \%$ guru memiliki kriteria kurang, dan $79 \%$ guru memiliki kriteria cukup.

Berdasarkan hasil pra siklus diatas, maka perlu ditingkatkan kompetensi pedagogik guru pada siklus pertama.

Pada siklus I (pertama)ini kegiatan yang dilakukan meliputi perencanaan, pelaksanaan, pengamatan dan refleksi. Kegiatan siklus I (pertama) dilakukan pada tanggal 03 - 15 September 2018.

1. Pada tahap perencanaan meliputi: Menyiapkan instrumen supervisi. Instrumen supervisi diperbanyak sesuai jumlah guru yang akan disupervisi. Kegiatan ini dilaksanakan pada hari sabtu tanggal 01 September 2018.

2. Tahap pelaksanaan

Pelaksanaan supervisi informal ini dilakukan secara tiba-tiba oleh kepala sekolah dengan melakukan observasi secara langsung melalui kunjungan kelas. Supervisi informal dilaksanakan dengan menggunakan Instrumen Pengukuran Kompetensi pedagogik guru Sesudah Pelaksanaan Pembinaan
Materi (Perencanaan Pembelajaran) dan Instrumen Pengukuran Kompetensi pedagogik guru Sebelum dan/atau Sesudah Pelaksanaan Pembinaan Pelaksanaan Pembelajaran (Observasi Kelas Implementasi Kurikulum 2013). Kunjungan kelas (Classroom Visitation) dilaksanakan mulai tanggal 03 - 15 September 2018. 3. Pengamatan dan evaluasi

Kepala sekolah melakukan pengamatan terhadap pembelajaran yang dilakukan oleh guru, jika ada kekurangan dalam pelaksanaan proses pembelajaran, kepala sekolah menegur langsung dan memperbaiki kekurangan dari guru saat proses pembelajaran. Berikut ini hasil siklus I (pertama)yang dilakukan oleh peneliti ditunjukan pada Diagram 2 sebagai berikut:

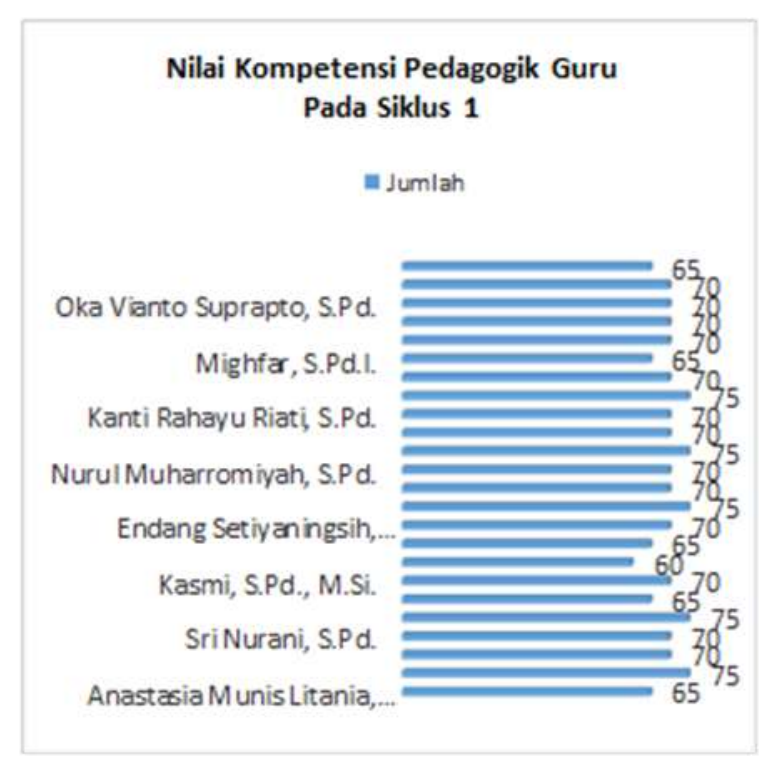

Diagram 2 Hasil kopetensi Pedagogik Guru pada siklus pertama

Berdasarkan hasil siklus I )pada Diagram 2 di atas, nilai rata-rata kompetensi pedagogik guru di SDN Margorejo I adalah 69,58. Nilai yang 
terendah adalah 60 dan nilai yang tertinggi adalah 75 .

4. Tahap refleksi. Berdasarkan analisis hasil pengamatan dan evaluasi pada siklus I (pertama)guru mengalami peningkatan dari pra siklus ke siklus pertama. Pada pra siklus kemampuan pedagogik guru yang memiliki kurang sebanyak $21 \%$, sedangkan guru memiliki kriteria cukup sebanyak 79 $\%$. Hal tersebut dikarenakan supervisi yang selalu di laksanakan selalu bersifat ilmiah, yang mana sebelum di supervisi guru selalu menyiapkan media, perangkat dengan baik. Tetapi jika waktu tidak di jadwalkan supervisi guru kembali seperti semula.

Berdasarkan pengalaman tersebut, maka peneliti mencoba menerapkan supervisi informal, yang dilakukan tanpa disadari guru dengan cara tiba-tiba. Berdasarkan kekurangan-kekurangan yang terjadi pada siklus I yang belum mencapai indikator pencapaian tindakan $80 \%$ guru menguasai kompetensi pedagogik baik, maka akan dilakukan perbaikan dalam pelaksanaan supervisi pada siklus II agar kompetensi pedagogik guru meningkat dengan baik. Berikut ini Tabel 2 hasil rekapitulasi siklus pertama.

Tabel 2 Rekapitulasi Siklus I

\begin{tabular}{|c|c|r|c|}
\hline Nilai & Jumlah & Prosentase & Kriteria \\
\hline 60 & 1 & $4,167 \%$ & Cukup \\
\hline 65 & 5 & $20,83 \%$ & Cukup \\
\hline 70 & 13 & $54,17 \%$ & Cukup \\
\hline 75 & 5 & $20,83 \%$ & Baik \\
\hline
\end{tabular}

Berdasarkan hasil Tabel 2 Rekapituasi siklus I terjadi peningkatan $20,83 \%$ pada kriteria baik, kriteria kurang sudah tidak ada lagi, sedangkan kriteria cukup tetap pada posisi $79 \%$..
Hal-hal yang perlu dilakukan untuk memperbaiki supervisi pada siklus berikutnya antara lain dengan cara: a) Memberikan sosialisasi saat rapat dengan guru tentang proses supervisi informal sehingga setiap hari guru harus selalu menyiapkan segala sesuatu sebelum proses pembelajaran di mulai baik media, perangkat, penguasaan kelas, mengelolaan kelas secara efektif, komunikasi yang efektif di kelas, b) Memberi motivasi guru agar setiap hari selalu berusaha mengelola pembelajaran dengan baik diawasi maupun tidak diawasi oleh kepala sekolah. Pada siklus I (pertama) ini indikator ketercapaian kompetensi pedagogik guru belum mencapai $80 \%$ baik, maka dari itu peneliti melanjutkan pada siklus II (kedua).

Pelaksanaan siklus II peningkatan kompetensi pedagogk guru melalui supervisi informal dilaksanakan pada 01 - 16 Oktober 2018 Siklus II (kedua) terdiri dari empat tahap yakni: (1) perencanaan, (2) pelaksanaan, (3) pengamatan dan evaluasi, dan (4) refleksi. Berikut ini adalah hasil siklus II (kedua):

1. Pada tahap perencanaan siklus II (kedua) meliputi: Menyiapkan instrumen supervisi. Instrumen supervisi diperbanyak sesuai jumlah guru yang akan disupervisi. Kegiatan ini dilaksanakan pada hari sabtu tanggal 29 Septeber 2018.

2. Tahap pelaksanaan

Pelaksanaan supervisi informal ini dilakukan secara tiba-tiba oleh kepala sekolah dengan melakukan observasi secara langsung melalui kunjungan kelas. Supervisi informal dilaksanakan dengan menggunakan Instrumen 
Pengukuran Kompetensi pedagogik guru Sesudah Pelaksanaan Pembinaan Materi (Perencanaan Pembelajaran) dan Instrumen Pengukuran Kompetensi pedagogik guru Sebelum dan/atau Sesudah Pelaksanaan Pembinaan Pelaksanaan Pembelajaran (Observasi Kelas Implementasi Kurikulum 2013). Kunjungan kelas (Classroom Visitation) dilaksanakan mulai tanggal $01-16$ Oktober 2018.

\section{Pengamatan dan evaluasi}

Kepala sekolah melakukan pengamatan terhadap pembelajaran yang dilakukan oleh guru, jika ada kekurangan dalam pelaksanaan proses pembelajaran, kepala sekolah menegur langsung dan memperbaiki kekurangan dari guru saat proses pembelajaran. Berikut ini hasil siklus I (pertama)yang dilakukan oleh peneliti:

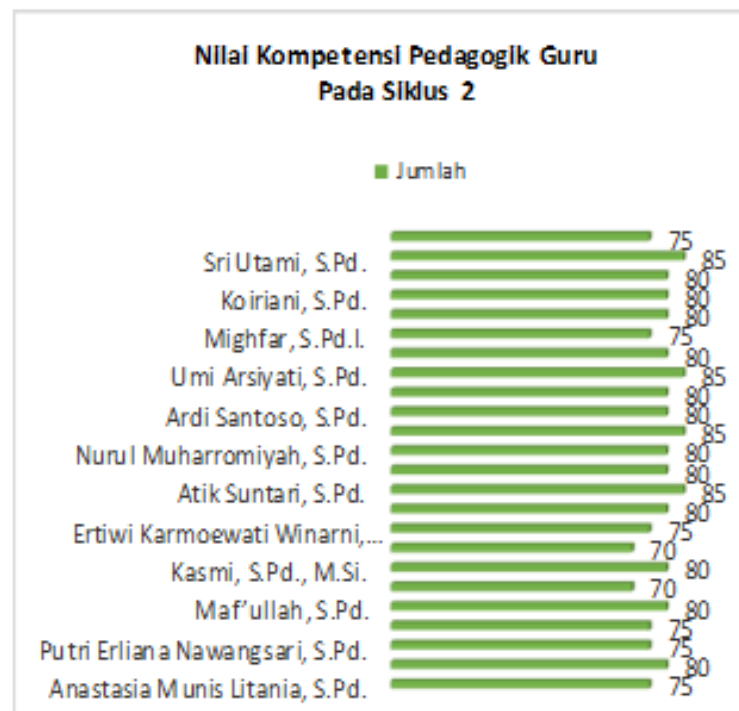

Diagram 3 Hasil kompetensi pedagogik guru pada siklus II

Berdasarkan pada Diagram 3 hasil siklus I nilai rata-rata kompetensi pedagogik guru di SDN Margorejo I adalah 78,75 . Nilai yang terendah adalah 70 dan nilai yang tertinggi adalah 85 .
4. Tahap refleksi

Berdasarkan analisis hasil pengamatan dan evaluasi pada siklus II (kedua) guru mengalami peningkatan dari siklus pertama. Pada siklus II kriteria kurang sudah tidak ditemukan. Berikut ini rekapitulasi pada siklus II (kedua):

Tabel 3 Rekapitulasi Siklus II (kedua)

\begin{tabular}{|c|c|c|c|}
\hline Nilai & Jumlah & Prosentase & Kriteria \\
\hline 70 & 2 & $8.33 \%$ & Cukup \\
\hline 75 & 6 & $25 \%$ & Baik \\
\hline 80 & 12 & $50 \%$ & Baik \\
\hline 85 & 4 & $16.67 \%$ & Baik \\
\hline
\end{tabular}

Berdasarkan hasil rekapituasi siklus II (kedua) terjadi peningkatan 70,82\% pada kriteria baik, yang pada siklus I (pertama)hanya $20,83 \%$ meningkat menjadi 91,67\%. Pada siklus II (kedua) ini indikator ketercapaian kompetensi pedagogik guru sudah mencapai lebih dari $80 \%$ baik, maka dari itu penelitian tindakan sekolah tentang peningkatan kompetensi pedagogik guru melalui supervisi informal sudah selesai karena sudah tercapai indikator ketercapaian penelitian tindakan sekolahnya. Pelaksanaan penelitian tindakan sekolah dalam meningkatkan kompetensi pedagogik guru melalui supervisi informal berhasil diterapkan dengan baik dan dapat meningkatkan kompetensi pedagogik guru di SDN Margorejo 1 Surabaya.

\section{SIMPULAN DAN SARAN Simpulan}

Berdasarkan pembahasan diatas, dapat disimpulkan sebagai berikut:

Supervisi informal dapat meningkatkan kompetensi pedagogik guru, hal tersebut dilihat dari peningkatan guru dari siklus ke siklus, pada pra siklus 
nilai rata-rata kompetensi pedagogik guru di SDN Margorejo I adalah 59,79 dengan $21 \%$ guru yang memiliki kriteria kurang, dan $79 \%$ guru memiliki kriteria cukup. Pada siklus I (pertama)terjadi peningkatan $20,83 \%$ pada kriteria baik, kriteria kurang sudah tidak ada lagi, sedangkan kriteria cukup tetap pada posisi $79 \%$. Pada siklus II (kedua) juga terjadi peningkatan sebesar 70,82\% pada kriteria baik, dari $20,83 \%$ pada siklus I (pertama)meningkat menjadi $91,67 \%$ pada silus kedua. Pada siklus II (kedua) ini indikator ketercapaian kompetensi pedagogik guru sudah mencapai lebih dri $80 \%$ baik

\section{Saran}

1. Kepala sekolah selaku supervisor bisa menggunakan supervisi informal karena supervisi ini bisa meningkatkan kompetensi pedagogik guru, dengan menggunakan supervisi informal guru setiap hari akan selalu siap untuk mengajar karena kepala sekolah tiba-tiba datang ke kelas untuk melihat proses pembelajaran.

2. Guru supaya menyiapkan diri sebelum memulai proses pembelajaran, baik perangkat pembelajarannya, media dan penggunaan strategi dan metode pembelajaran yang bervariasi.

3. Hendaknya guru lebih meningkatkan kompetensi pedagogiknya agar dapat meningkatkan mutu pembelajaran.

4. Perlu adanya penelitian lanjuatan tentang supervisi informal untuk meningkatkan kompetensi yang lain.

\section{DAFTAR RUJUKAN}

Akhyak, I.M dan Bakar, Y.A. 2013. Implementation of teachers pedagogy competence to optimizing learners development in public primary school in indonesia. International journal of education and research, 1(9): 3 .

Mata, Liliana. 2014. Pedagogical Competencies For Mother Tongue Teacher Education. Education science \& practice International journal, 14 (1):346347.

\section{Peraturan Menteri Pendidikan Nasional} Republik Indonesia Nomor 16 Tahun 2007 Tentang Standar Kualifikasi Akademik Dan Kompetensi Guru.

Peraturan Menteri Pendidikan Nasional Republik Indonesia Nomor 13 Tahun 2007 Tentang Standar Kepala Sekolah/Madrasah.

Pidarta, Made. 2009. Supervisi Pendidikan kontekstual. Jakarta: Rineka Cipta.

Sergiovanni, T. J., \& Starratt, R. J. (1993). Supervison : redefinition . New York: McGraw-Hill, INC.

Usman, Husaini dan Akbar, Purnomo Setiadi. 2014. Metodologi Penelitian Sosial. Jakarta: Bumi Aksara. 